\author{
JERZY RAJMAN \\ UNIWERSYTET PEDAGOGICZNY W KRAKOWIE
}

\title{
WKŁAD KLASZTORÓW W ROZWÓJ KULTURY ORGANOWEJ ŚREDNIOWIECZNEJ I WCZESNONOWOŻYTNEJ MAŁOPOLSKI (OD XIV DO KOŃCA XVI W.)
}

๑ 1 ożna organy umieścić przy ścianie muru, tak aby od wnętrza kościoła nic tylko miechy [...] nad organami można powiesić na sznurze u sufitu grube płótno napięte od środka drewnianymi listwami na podobieństwo namiotu, dla ochrony przed kurzem”. Tymi słowami mnich benedyktyński Teofil kończył opis, pochodzący z przełomu XI i XII w., poprzedzony drobiazgową, ale i przystępną, instrukcją wytwarzania piszczałek, miecha, wiatrownic oraz łączenia ich w instrument ${ }^{\mathrm{I}}$. Zakonnicy posiadali więc warsztat, procedurę i umiejętności dla samodzielnego zbudowania instrumentu. Interesującym problemem badawczym jest znajomość dzieła mnicha Teofila w polskich klasztorach. Odkładając go do osobnego studium, stwierdzić na razie możemy, że wkład zakonów w rozwój kultury organowej został w literaturze doceniony i podkreślony ${ }^{2}$. Na uwagę zasługuje rozprawa Jerzego Mizgalskiego, podkreślającego znaczenie organmistrzostwa klasztornego dla rozwoju kultury muzycznej, publikującego dane, siłą rzeczy niepełne, o organistach i organmistrzach klasztornych średniowiecznej Polski³. Jerzy Gołos, nestor badań nad polską organologią dawną, pisał, w kontekście średniowiecznego organmistrzostwa, że klasztory miały

I Teofil Prezbiter, Diversarum Artium Schedula, przekł. Stanisław Kobielus, Kraków I998, s. I36-I43.

2 Peter F. Williams, A new history of the organ from the Greeks to the present day, Bloomington I980, s. 47. Termin „kultura organowa” stosujemy dla ogółu zagadnień takich, jak proces wyposażania kościołów w organy, środowisko organistów i organmistrzów, rozwiązania techniczne instrumentów, muzyka organowa itd. Zdaję sobie sprawę, że brzmi on nieco sztucznie. Użył go w nowszej literaturze przedmiotu dla XIX w. Maciej Babnis (Kultura organowa Galicji, Słupsk 20I2), ale z powodzeniem może on być stosowany także dla innych epok.

3 Jerzy Mizgalski, „Organiści i organmistrze polscy jako źródło rozprzestrzeniania się muzyki profesjonalnej na terenie Polski do końca XVIII w.", w: Prace naukowe Instytutu Muzykologii Uniwersytetu Warszawskiego, t. I, Warszawa I96I, s. 65-66, 67. Pani Iwonie Januszkiewicz-Rębowskiej z Biblioteki Instytutu Muzykologii Uniwersytetu Warszawskiego dziękuję za przesłanie mi skanu tej książki. 
„zaawansowane zaplecze technologiczne i surowcowe”4. Kwestii ich wpływu na rozwój organmistrzostwa jednak nie omawia, nie wyodrębnia wkładu klasztorów jako osobnego tematu badawczego5. Katalog, który ułożył Jerzy Gołos w książce The Polish organ (Warszawa 1992), skierowanej do obcych badaczy, jest niestety bardzo niekompletny, niedokładny i nie daje obrazu procesu historycznego powstawania organów i ich rozmieszczenia w poszczególnych kościołach, zwłaszcza gdy idzie o epoki wcześniejsze (średniowiecze i wiek XVI). W polskiej literaturze historycznej poświęconej poszczególnym zakonom i w monograficznych ujęciach poszczególnych klasztorów temat organów klasztornych wprawdzie czasami się pojawia, ale daleko jest do jego wyczerpania.

Podejmując próbę całościowego spojrzenia na to zagadnienie w odniesieniu do średniowiecznej Małopolski, zaznaczyć musimy, że struktura kościelna tej olbrzymiej prowincji, na którą składało się kilkadziesiąt klasztorów (domy główne i filialne), daje obfity materiał do badań. O trudnościach badawczych decyduje ogromnie rozproszona baza źródłowa. Składają się na nią materiały źródłowe wytworzone przez klasztory (rachunki, inwentarze, nekrologi), jednakże pierwsze wzmianki źródłowe o organach i organistach klasztornych pochodzą, w większości przypadków, z rękopiśmiennych akt sądowych biskupa i oficjała krakowskiego z XV i XVI w., z protokołów powizytacyjnych oraz z ksiąg miejskich. Zarys niniejszy prezentuje obecny stan kwerendy. Należy zastrzec, że dalsze badania z pewnością pozwolą na uzupełnienia i korekty. Wydaje się jednak, że zasadnicze kontury omawianej problematyki nie ulegną zmianie.

Który z klasztorów małopolskich jako pierwszy posiadał organy? Może klaryski starosądeckie kultywujące w XIV w. muzykę szkoły Notre Dame, a może kanonicy regularni, słynni dzięki powstałej w Kraśniku tabulaturze Jana z Lublina? Jako sztandarowy przykład pionierskiej roli zakonów w budowie „króla instrumentu” przywołuje się zawsze postać organisty Tomasza, dominikanina z klasztoru św. Jakuba

4 Jerzy Gołos, Polskie organy i muzyka organowa, Warszawa I972, s. 35-40.

5 Ibid., s. 9. Problematykę wkładu poszczególnych zakonów w rozwój kultury organowej podejmowali dla dominikanów: Waldemar Kapeć, Organy i organiści w polskich klasztorach dominikańskich od XIII do XX w., Lublin 1998; Wiktor Z. Łyjak, „Organy i dokumenty na temat organów dominikańskich w zbiorach obcych”, w: Dominikanie. Gdańsk - Polska - Europa, red. Dariusz Aleksander Dekański, Gdańsk-Pelplin 2003, s. 689-757; dla franciszkanów: Wiktor Z. Łyjak, „Organy w kościołach franciszkanów konwentualnych na terenie Małopolski”, Studia Franciszkańskie Io (1999), s. 289-326; dla bernardynów: Wiktor Z. Łyjak, „Budownictwo organowe w zakonie bernardynów. Najstarsze kontrakty i opisy”, w: Zakony franciszkańskie $w$ Polsce, t. 2, Franciszkanie w Polsce XVI-XVIII wieku, cz. 2, red. Jerzy Kłoczowski, Niepokalanów 2003, s. 208-230 (istnieje także niepublikowana praca Mieczysława Śmierciaka Organy w kościołach bernardyńskich na terenie Polski. Studium historyczno-instrumentoznawcze, Lublin 2008, podaję za: Maria Szymanowicz, Polska bibliografia organów, t. 2, Lublin 20I4, s. 86, pozycja I762); dla cystersów: Wiktor Z. Łyjak, „Organowe dziedzictwo cystersów w Polsce”, w: Pelplin. 725. rocznica powstania opactwa cysterskiego. Kulturotwórcza rola cystersów na Kociewiu, red. Dariusz Aleksander Dekański, Bernard A. Grenx, Alicja Słyszewska, Andrzej M. Wyrwa, Pelplin-Tczew 2002, s. 20I-240. Zagadnienie znaczenia klasztorów w organologii pojawia się także w pracach ogólniejszych, poświęconych historii muzyki, których wymieniać tu nie sposób. 
w Sandomierzu, zamordowanego wraz z 49 zakonnikami przez Tatarów w I259-60 roku. Teza o obecności organisty w sandomierskim konwencie dominikańskim w XIII w. musi być poddana krytyce. W I259 r. Tatarzy najechali na Małopolskę, ich ofiarą padło kilka miast, w tym Sandomierz. Informuje o tym szereg źródeł ${ }^{6}$. Tradycja dominikańska złączyła z tym najazdem legendę o hekatombie konwentu sandomierskiego. Najstarsze spisy dominikanów zamordowanych podczas najazdu tatarskiego w I259 r. pochodzą jednak dopiero z drugiej połowy XVIII w. ${ }^{7}$. Nie da się wykazać, że u św. Jakuba była przechowywana aż do drugiej połowy XVIII w. lista odnosząca się do I259-6o roku. Założyć należy raczej, że mglista pamięć o męczennikach była w miarę stuleci wzbogacana szczegółami zaczerpniętymi z przekazów niewiadomego pochodzenia. Podtrzymywanie tezy, że w I259-60 r. wzmiankowany jest Tomasz organista i dominikanin sandomierski, wymagałoby najpierw weryfikacji całej listy pięćdziesięciu męczenników, a tego nie jesteśmy w stanie zrobić. Przyczyną jest brak źródeł do badań prozopograficznych konwentu sandomierskiego w XIII wieku. Moją wątpliwość budzi także liczba pomordowanych w I259-60 roku. Obecność pięćdziesięciu zakonników w trzynastowiecznym Sandomierzu nie wydaje się prawdopodobna. W I226 r. przybyła tu z Krakowa „mała grupa braci”. Konwent z pewnością rozrastał się, ale nic nie potrafimy powiedzieć na temat liczby zakonników w chwili, gdy do miasta wtargnęli Tatarzy. Sądzę, że kilkudziesięciu zakonników

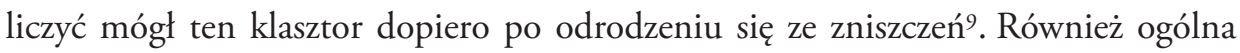
wiedza na temat powstawania instrumentów przeczy tezie o organach sandomierskich w I259-60 r. - od okrzepnięcia danej instytucji kościelnej do instalacji instrumentu upływało zawsze sporo czasu. Koszt tego przedsięwzięcia był wysoki - kościół Mariacki w Krakowie zdobył się na instrument muzyczny dopiero w ponad sto lat po lokacji miasta. Był to przecież kościół o wielkich dochodach własnych, a dodatkowo na jego wyposażenie łożyła bogata gmina mieszczańska. I wreszcie - pierwsze wiarygodne wzmianki o organach u krakowskich dominikanów pochodzą dopiero z XV wieku. Filialny klasztor wyprzedziłby zatem macierzysty o dwieście lat?

Odkładając na bok, jako trudną do pozytywnej weryfikacji, tezę o organiście dominikańskim Tomaszu, stwierdzić zarazem musimy, że z XIII w. nie ma jakichkolwiek

6 Aleksander Semkowicz, Krytyczny rozbiór Dziejów Polskich Jana Dtugosza (do roku 1384), Kraków I887, s. $278-280$.

7 Krzysztof Stopka („Męczennicy sandomierscy - legenda i rzeczywistość”, Nasza Przesztość 80 (1993), s. 92) podaje, że osiemnastowieczni autorzy powoływali się na listę w archiwum dominikanów sandomierskich, ale nie wypowiada się na temat jej wiarygodności. Waldemar Kapeć (op. cit., s. 6I) przyjmuje wzmiankę z I259 r. o organiście Tomaszu za wiarygodna; takie samo stanowisko prezentuje w swej innej publikacji, zob. tegoż, „Życie muzyczne w lubelskim klasztorze dominikanów”, w: Dominikanie w Lublinie. Studia $z$ dziejów i kultury, red. Henryk Gapski, Lublin 2006, s. 237; podobnie Jerzy Mizgalski (op. cit., s. 6I).

8 Jerzy Kłoczowski, „Zakon Braci Kaznodziejów”, w: Studia nad historia dominikanów w Polsce (I222-1972), red. Jerzy Kłoczowski, Warszawa 1975, s. 26.

9 Jerzy Kłoczowski pisze, że „normalna liczba zakonników w największych domach wynosiła kilkadziesiąt osób” (ibid., s. 3I) oraz wskazuje na rangę klasztoru sandomierskiego w XIII w. (ibid., s. 39). 
wzmianek o organach nie tylko w kościołach klasztornych, ale w ogóle w kościołach ówczesnej Małopolski. Trudno powiedzieć, na ile jest to odzwierciedlenie rzeczywistości, na ile zaś wprowadza nas w błąd słaba dokumentacja źródłowa. Brak przekazów źródłowych o organach jaskrawo kontrastuje przecież z ogólnymi danymi o kulturze muzycznej danego ośrodka klasztornego - w tym przypadku nasuwają się przykłady opactwa benedyktynów w Tyńcu i klasztoru klarysek w Starym Sączu, czy też kanoników regularnych również znanych z wysokiej kultury muzycznej.

Historia organów w małopolskich klasztorach zaczyna się - jeśli opieramy się na wiarygodnej dokumentacji źródłowej - dopiero w drugiej połowie XIV wieku. Pierwszym zakonem, który zdobył się na instrument w swoim kościele, byli bożogrobcy w Miechowie. Dysponują oni bowiem w pełni wiarygodnym przekazem z 1376 r. mówiącym, że prepozyt Marcin Czcik wybudował organy w kościele klasztornym, będącym zarazem świątynią parafialną ${ }^{10}$. Dla innych zakonów nie mamy równie wczesnych informacji źródłowych. Ktoś znający dobrze źródła może jednak powiedzieć, że przecież już w I37I r. były naprawiane organy w kościele Bożego Ciała w mieście Kazimierzu. Istotnie tak było, ale pamiętać musimy, że kanonicy regularni osiadli w tym kościele dopiero w I4Os roku. Odegrali jako zakon wielką rolę w rozwoju kultury muzycznej, ale gwoli ścisłości trzeba powiedzieć, że organy odziedziczyli po rajcach kazimierskich wraz z kościołem. Miechów stanowi ciekawy przypadek, gdyż wzmianka o wybudowaniu organów wyprzedza w czasie wzmiankę o organiście - zazwyczaj jest odwrotnie. Pozwala ona na wyjątkowo ścisłe datowanie zainstalowania instrumentu w kościele klasztornym. W I42I r. wzmiankowany jest brat Andrzej, bożogrobiec będący organistą klasztornym ${ }^{\mathrm{II}}$, a w 1. I468-69 muzykiem był kanonik $\mathrm{Jan}^{12}$, również bożogrobiec. Przypuszczam, że organiści-zakonnicy akompaniowali podczas nabożeństw chórowych. Na podstawie źródeł z XVI w. można wnioskować, że nabożeństwa parafialne obsługiwali muzycy świeckiego pochodzenia. Byli nimi np. Piotr Szurdej, wymieniony w testamencie Macieja Miechowity z 1. I5I4-I8. To niewątpliwie on jako organista Piotr z Miechowa wraz ze słynnym organmistrzem Stanisławem Warpaszką, podjęli się, w I5I9 r., budowy organów dla kolegiaty w Sandomierzu ${ }^{13}$. Kolejny to Wojciech, organista z Miechowa, odnotowany w I528 r. w sporze z organistą Stanisławem Słowikiem z Krakowa ${ }^{14}$. Dodam jeszcze, że w wykazie po-

IO Rocznik miechowski, wyd. Zofia Kozłowska-Budkowa, Studia Źródtoznawcze 5 (I960), s. I26.

II Zbiór dokumentów katedry i diecezji krakowskiej, t. 2, wyd. Stanisław Kuraś, Lublin I973 (cyt. dalej ZDK), nr 238.

I2 AGAD perg 2613; Cracovia artificum supplementa I462-I475, opr. Bolesław Przybyszewski, Kraków 2000 (cyt. CASupp. I462-75), $\mathrm{nr}$ II4.

I3 Wypisy źródtowe do dziejów Wawelu z archiwaliów kapitulnych i kurialnych krakowskich I5I6-I525, opr. Bolesław Przybyszewski, Kraków I970, nr I2I; Archiwum Kurii Metropolitalnej w Krakowie (cyt. AKM), Acta Officialatus Cracoviensis (cyt. Off.), t. 35, k. 805 .

I4 Wypisy źródtowe do dziejów Wawelu z archiwaliów kapitulnych i kurialnych krakowskich I526-I529, opr. Bolesław Przybyszewski, Kraków 1984, nr 204. 
bierających pensję z klasztoru, sporządzonym w I593 r., figuruje pozycja „organista” z zaskakująco wysokim uposażeniem 50 florenów, wyższym niż pensja ówczesnego „starosty” miechowskiego ${ }^{15}$. O należącym do bożogrobców kościele św. Jadwigi na Stradomiu pod Krakowem wiadomo, że posiadał tzw. regał i jego naprawą zajmował się pod koniec XVI w. tamtejszy prepozyt Szymon Turski ${ }^{16}$.

Pozostając w kręgu zakonów kanonickich, wskażemy, że kanonicy regularni objęli w I405 r. kościół parafialny Bożego Ciała w Kazimierzu koło Krakowa. Jak już wspomniałem, kościół ten posiadał, w okresie przedzakonnym, organy wzmiankowane w I37I roku. Zostały ukończone w latach siedemdziesiątych XIV w. przez mistrza Marcina opłacanego z kasy miejskiej ${ }^{17}$. W opracowaniach można napotkać na obfity wykaz organistów kościoła Bożego Ciała w okresie, gdy kościół ten należał do kanoników regularnych. Przytoczymy go, zastrzegając, że powinien być poddany szczegółowej weryfikacji. W XV w. grali Jakub, Maciej, Mikołaj, Błażej z Dobczyc, Stanisław, a w XVI w. - Jan z Pilzna, Kacper z Gródka, Wincenty, Jan Wadovius, Andrzej, podprzeor Adam, Stanisław Bednarz i Jan ${ }^{18}$. W posiadaniu Andrzeja, organisty w kościele Bożego Ciała w Kazimierzu, znajdowała się tabulatura, którą po jego śmierci w I5I7 r. przejął Augustyn z Kazimierza ${ }^{19}$. Jest to najstarsza wzmianka o tabulaturze organowej, która niestety nie zachowała się. Organy w kościele Bożego Ciała spłonęły w I594 r. ${ }^{20}$. Kanonicy kazimierscy mieli swoje klasztory filialne w Kłobucku (I454), Kraśniku (I468) i Kurozwękach (I487). W miastach tych, podobnie jak w macierzystym Kazimierzu, przejęli miejscowe kościoły parafialne ${ }^{21}$, a zatem w kwestii organów musimy uwzględniać potrzeby liturgii dla laików. W Kłobucku, w kościele będącym zarazem parafią, jak i świątynią konwentualną, organy są poświadczone pod koniec XVI w. wraz z adnotacją, że prepozyt klasztoru utrzymuje kantora, rektora szkoły i organistę $e^{22}$. W Kraśniku, najważniejszym miejscu nowożytnej kultury organowej, w tamtejszym kościele kanoników pierwszym znanym nam organistą był Paweł działający na przełomie XV/XVI w. ${ }^{23}$. Kolejni to: kanonik Jan z Lublina, zmarły 14 XI 1552 r., kanonik Walenty z Sędziszowa, zmarły w I572 r., Kacper Kossecki

22 AKM, Acta Visitationis Capituli (cyt. dalej AVCap.), 32, k. 9IV.

23 J. Mizgalski, op. cit., s. 69.

Biblioteka Narodowa w Warszawie, rps BOZ I289, s. Io6. tę podał Jerzy Gołos (The Polish organ, Warszawa I992, s. 260).

K. Łatak, op. cit., s. II4.

Kraków I997, s. 382,413 .

Akta wizytacji dekanatu krakowskiego z I599 r., wyd. Czesław Skowron, cz. I, Lublin 1965, s. I52. Nie napotkałem na źródło z I466 r. dowodzące, że w kościele św. Jadwigi były wówczas organy. Wiadomość

Ksieggi radzieckie kazimierskie I369-8I i 1385-I402, wyd. Adam Chmiel, Kraków 1932, s. 53; por.: Kazimierz Łatak, Kanonicy regularni laterańscy na Kazimierzu w Krakowie do końca XVI wieku, Ełk I999, s. IOO.

Adolf Chybiński, Stownik muzyków dawnej Polski do r. I80o, Kraków 1949, s. I, 48, 54, 79, 84, II8;

J. Mizgalski, op. cit., s. 80; K. Łatak, op. cit., s. 63, s. I80, przyp. 200, s. 272, przyp. 40.

AKM, Off. 4I, s. 360; wiadomość tę wprowadził do literatury Kazimierz Łatak (op. cit., s. 272).

Ibid., s. 86 i nast.; Janusz Kurtyka, Tęczyńscy. Studium zdziejów polskiej elity możnowtadczej wśredniowieczu, 
z Myślenic, wzmiankowany jako organista w 574 r., i kanonik Piotr z Parczewa, odnotowany jako organista w I58I r. ${ }^{24}$. Tabulatura Jana z Lublina, powstała około I540 r. w klasztorze kanoników regularnych w Kraśniku, stanowi największy europejski zbiór utworów organowych z XVI w. ${ }^{25}$. Kościół w Kurozwękach był pod koniec XVI w. sprofanowany przez innowierców, w protokole powizytacyjnym organów w nim nie wykazano ${ }^{26}$, co niekoniecznie musi w takich przypadkach odpowiadać rzeczywistości - organów w tym źródle nie wykazano także w kościele kanonickim w Kraśniku ${ }^{27}$, choć przywołana wyżej długa lista organistów dowodzi ich istnienia. Co do klasztoru kanoników regularnych w Mstowie, najwcześniejsza informacja znana z literatury mówi, że organy zdemontowano ok. I630 r. ${ }^{28}$. Mogły zatem istnieć w XVI wieku. O przeszłości tego instrumentu nic nie wiemy. Nie mamy także żadnych informacji o organach w kościele kanonickim w Krzepicach, choć ich istnienie wydaje się prawdopodobne.

W kościele klasztornym św. Ducha w Krakowie, prowadzonym przez kanoników-szpitalników, organista Franciszek jest poświadczony w I443 r. ${ }^{29}$. Kolejnym był Walenty odnotowany w 1475 r. ${ }^{30}$. Identyfikować go możemy z mieszczaninem krakowskim Walentym Messerschmidem z Cieszyna, organistą u św. Ducha, który grał w tym kościele jeszcze w I509 r. ${ }^{31}$. W I49I r. poświadczony został organista Maciej w sprawie sądowej z innym organistą, Kacprem z Gródka ${ }^{32}$. Organistą u duchaków był w I528 r. nieznany bliżej Jan33. W I534 r. klasztor ten toczył spór o dwa cetnary cyny, które mieszczka krakowska Katarzyna Paulusowa z Pilicy przeznaczyła na wybudowanie organów w kościele Krzyża Świętego ${ }^{34}$. Troska o instrument jest w pełni zrozumiała, zwłaszcza zważywszy na to, że w klasztorze tym powstał ok. 1548 r. zbiór utworów na organy znany jako tabulatura klasztoru św. Ducha

24 Ewa Zielińska, Kultura intelektualna kanoników regularnych z klasztoru $w$ Kraśniku w latach I469-I563, Lublin 2002, s. 69, 70, I46, I47, I54. O organiście Janie z Lublina zob. także K. Łatak, op. cit., s. 88.

25 E. Zielińska, op. cit., s. IIO, II4, I44, I46 (literatura na temat tabulatury Jana z Lublina tamże s. 85, 88); Paweł Gancarczyk, „Uwagi kodykologiczne o tabulaturze Jana z Lublina”, Muzyka 4I (I996) nr 3, s. 45-58; Jan Chwałek, „Traktat Ad faciendam corecturam z Tabulatury organowej Jana z Lublina (I540 r.)”, w: Organy i muzyka organowa, t. 6, Gdańsk 1984, s. 19-40.

26 AKM, AVCap. Io, k. I5-17.

27 AKM, AVCap. I2, s. IO-II.

28 W.Z. Łyjak, „Organy i dokumenty na temat organów dominikańskich”, op. cit., s. 698.

29 AKM, Off. 6, k. 476.

30 CASupp. I462-75, nr 255; także w AKM, Off. 2, k. 559, 568v, 634v.

3I AKM, Off. I3, s. I357; także w Off. I5, k. I45; Off. 26, s. III. W I48I r. przyjął obywatelstwo Krakowa, Księgi przyjęć do prawa miejskiego w Krakowie 1392-I506, wyd. Kazimierz Kaczmarczyk, Kraków I9I3, nr 7971. Jego postać jest stosunkowo dobrze opisana w źródłach, występuje np. jako osoba chora na febrę, doznająca cudu za wstawiennictwem św. Szymona z Lipnicy, Archiwum OO. Bernardynów w Krakowie, rps I-e-I, k. 32; także w AKM, Off. 2, s. 223, 559, 568v, 634v.

32 Bolesław Przybyszewski, Krakowskie środowisko artystyczne czasów Wita Stwosza, Kraków I990, s. I84.

33 Bolesław Przybyszewski, Artyści i rzemieślnicy krakowscy w latach I526-I535, Kraków I985, nr I80.

34 Ibid., nr II88. 
w Krakowie ${ }^{35}$. Wszystkie te dane jednoznacznie wskazują, że krakowski klasztor Ducha Świętego był wybijającym się ośrodkiem muzyki organowej.

W kościele premonstratensów w Brzesku-Hebdowie, najstarszym domu tej reguły w Polsce, posiadającym wyjątkowo słabą dokumentację źródłową nie tylko w kwestii muzyki, organy istniały prawdopodobnie już w XV wieku. Domysł ten opieramy na dwu pośrednich przesłankach. W I464 r. Marek, organista z Brzeska, wykonywał jakieś poważne prace dla jednego z klasztorów żeńskich ${ }^{36}$. Trudno tę postać jednoznacznie zidentyfikować. Chyba nie był to premonstratens; z interesującym nas opactwem wiązać go można tylko poprzez nazwę miejscowości. Mógł to jednak być organista nie w kościele klasztornym, ale w miejskim, będącym pod zwierzchnictwem klasztoru premonstratensów. Z I475 r. pochodzi wzmianka o umowie między opatem premonstratensów w Brzesku-Hebdowie, a Adamem, klerykiem z Kościelca, w sprawie jakiejś pracy przy organach ${ }^{37}$. Niestety nic dokładniej nie napisano. Organy odnotowano pod koniec XVI w. w opactwie premonstratensów w Nowym $\mathrm{Saczu}^{38}$.

Pierwszym organistą krakowskiego kościoła św. Marka, należącego do kanoników regularnych od pokuty błogosławionych Męczenników, był Daniel z Krakowa, poświadczony W I54I r., zarazem podprzeor, następnie przeor i generał zakonu ${ }^{39}$. W drugim małopolskim klasztorze tej reguły, we wsi Trzciana, pod koniec XVI w. odnotowany jest regał ${ }^{40}$.

Cytowany na początku tego artykułu mnich Teofil był benedyktynem. Wkład mnichów reguły św. Benedykta do światowej kultury muzycznej jest, choćby za sprawą Gwidona z Arezzo, doniosły i niepodważalny. O stosunkowo wczesnym powstaniu organów w kościele opactwa benedyktynów w Tyńcu możemy wnioskować z faktu, że już w I405 r. wzmiankowany jest organista Jan, tamtejszy mnich ${ }^{41}$. Można przypuszczać, że organy w tym kościele istniały pod koniec XIV wieku. Czas jego muzykowania przypada, co godne podkreślenia, na rządy zasłużonego dla naszej kul-

35 Na temat tabulatury klasztoru św. Ducha zob. E. Zielińska, op. cit., s. I45; Barbara Brzezińska, Repertuar polskich tabulatur organowych z pierwszej potowy XVI wieku, Kraków I987; Krzysztof Urbaniak, „Liturgiczna muzyka renesansowych tabulatur Polski południowej a instrumentarium organowe pierwszej połowy XVII wieku. O stylu południowo-polskim w budownictwie organowym wczesnego baroku", Musica sacra 6 (20IO), s. 87-IIO.

36 CASupp. I462-75 nr 42; AKM, Off. I2, s. 397.

37 AKM, Off. 2, k. I70.

38 AKM, AVCap. 9, s. I50.

39 AKM, Off. 65, k. 22I. Jego karierę zakonną opisuje Andrzej Bruździński, Kanonicy regularni od pokuty na ziemiach polskich, Kraków 2003, s. 334; tegoż, „Kanonicy regularni od Pokuty w Rzeczypospolitej Obojga Narodów”, w: Studia z dziejów kościoła św. Marka w Krakowie, red. Zdzisław Kliś, Kraków 200I, s. 43.

40 AKM, AVCap. 7, k. I82.

4I Wymieniony jest wśród mnichów tynieckich na dokumencie opata Mścisława z 20 II I405 r., zob.: Zbiór dokumentów matopolskich, t. I-8, wyd. Stanisław Kuraś, Irena Sułkowska-Kuraś, Kraków-Wrocław i962-75 (cyt. ZDM), tu t. 2, nr II78. Organistów opactwa tynieckiego zestawił Michał Gronowski, Zwyczajny klasztor, zwyczajni mnisi. Wspólnota tyniecka w średniowieczu, Kraków 2007, s. 27I-272. 
tury muzycznej opata Mścisława ${ }^{42}$. W Tyńcu na organach grali także Mikołaj (I433), Maciej (I466-82), Mikołaj z Brzeska (I497), Paweł (I5IO), Maciej z Krakowa (I5I5) i Maciej $(1526-43)^{43}$. Niejasno natomiast przedstawia się kwestia organów w kościele benedyktyńskim na Łysej Górze. Tadeusz M. Trajdos wykazał, że w nowożytnej tradycji klasztornej fundacja organów w kościele św. Krzyża przypisana jest królowi Władysławowi Jagielle ${ }^{44}$. Królewska fundacja organów - absolutny ewenement w tym czasie - zagościła już w literaturze, nawet z datowaniem jej na lata dziewięćdziesiąte XIV w. ${ }^{45}$. Zaangażowanie króla Władysława w rozwój łysogórskiego ośrodka pielgrzymkowego jest kwestią powszechnie znaną. W rachunkach królewskich dokumentujących szczegółowo prace budowlane finansowane przez króla Władysława Jagiełłę nie ma jednak ani jednej pozycji, która wskazywałaby na ufundowanie przez monarchę organów. Koszt budowy instrumentu był tak duży, a rachunki tak szczegółowe, że niemożliwe wydaje się, aby przeoczono ten wydatek. W nowożytnej tradycji klasztornej utrwaliła się pamięć, że organy spłonęły w pożarze w $4559 \mathrm{r}^{{ }^{46}}$, co oznacza, że jakiś instrument jednak był. Co do benedyktyńskiego Sieciechowa, to protokół powizytacyjny z końca XVI w. nie daje żadnych informacji o istnieniu organów ${ }^{47}$. Jednak Józef Gacki znał dokument o zarządzeniu opata z I604 r., aby zwiększyć uposażenie organisty w Sieciechowie $^{48}$, to zaś oznaczałoby istnienie organów w XVI wieku. Na mapie organów klasztornych zaznaczył się nawet maleńki benedyktyński Tuchów. Pod koniec XVI w. w tamtejszym kościele parafialnym, będącym pod administracją benedyktynów, odnotowano instrument oraz organistę, który mieszka w domu na cmentarzu ${ }^{49}$.

Z klasztorem dominikanów krakowskich łączy się najstarszy polski wizerunek średniowiecznych organów. Jest nim wykonany w l. I430-40 witraż kościoła Trójcy Świętej w Krakowie, który przedstawia postać anioła grającego na portatywie ${ }^{50}$. Instrument ten istniał z pewnością w tym czasie w kościele św. Trójcy. W dokumencie z 1440 r. wymieniony jest Piotr z Poznania, organista, dominikanin krakowski ${ }^{\text {II }}$.

42 Tadeusz Bratkowski, „Antyfonarz Mścisława z Tyńca w świetle tradycji polskiej i europejskiej”, Muzyka 49 (2004) nr 3, s. I63-165.

43 AKM, Off. 5, k. 7; M. Gronowski, op. cit., s. $27 \mathrm{I}$.

44 Tadeusz M. Trajdos, „Benedyktyni na Łyścu za panowania Władysława Jagiełły”, Roczniki Historyczne 48 (1983), s. 25.

45 Marek Derwich pisze, że w wyniku rozbudowy z lat dziewięćdziesiątych XIV w. kościół klasztorny otrzymał nowe organy, zob. tegoż, „Łysogórski ośrodek pielgrzymkowy”, w: Peregrinationes. Pielgrzymki $w$ kulturze dawnej Europy, red. Halina Manikowska, Hanna Zaremska, Warszawa I995, s. 280.

46 T.M. Trajdos, op. cit., s. 25.

47 AKM, AVCap. 9, s. 592.

48 Józef Gacki, Benedyktyński klasztor Świętego Krzyża na Eysej Górze, Warszawa 1873, s. I89. Gacki podał także informację (s. 158) o Marcinie Trwalińskim, organiście i benedyktynie w Sieciechowie, zmarłym w I679 roku.

49 AKM, AVCap. 7, k. 24.

50 Jerzy Banach, Tematy muzyczne w plastyce polskiej, t. I, Malarstwo, rzeźba, Kraków I956, il. 6.

5I ZDK 2, nr 406; Waldemar Kapeć (op. cit., s. 37) niezbyt ściśle podaje, że w I440 r. Piotr z Poznania objął funkcję organisty. On już był organistą, a w I440 r. został po prostu wzmiankowany wraz z innymi dominikanami krakowskimi. Wzmiankę o Piotrze organiście dominikańskim podaje także Chybiński (op. cit., s. 30). 
Przytoczyć można pomijaną w literaturze wiadomość, że na dokumencie z I4IO r. wystawionym w klasztorze dominikanów krakowskich świadkuje jako pierwszy Jakub, organista „de Sandecz" ${ }^{2}$. Jego pobyt w klasztorze nie był przypadkowy, zapewne wiązał się z jakąś pracą, prawdopodobnie z instalacją organów. Istnienie organów w kościele dominikańskim w Krakowie możemy datować najpóźniej na pierwszą dekadę $\mathrm{XV}$ wieku. Oprócz wspomnianego wyżej dominikanina Piotra, znamy także imiona kilku innych organistów u krakowskich dominikanów. Byli nimi Błażej z Krakowa (I485), Feliks (I519), Grzegorz Kunza (I520-32), Józef (I53I), Jan (I535) $)^{33}$ i Jan z Lelowa (I56I r.) $)^{54}$. W klasztorze dominikanów św. Marii Magdaleny w Sandomierzu organista Mikołaj został odnotowany w I524 r.55. W I550 r. lubelski konwent dominikanów toczył spór z organmistrzem Janem o dokończenie budowy organów. Wywodzący się z tego konwentu organmistrz Benedykt stawiał po 1538 r. organy w Płocku ${ }^{56}$. W kościołach będących pod zarządem dominikanów w Opatowcu i Żmigrodzie odnotowano pod koniec XVI w. regał ${ }^{7}$. Organistą w kościele dominikanów w Bochni był zakonnik Melchior zmarły w I6I5 $\mathrm{r}^{58}$. Brak przez całe średniowiecze i pierwszy wiek nowożytności wzmianek o organach w najstarszym sandomierskim kościele dominikańskim św. Jakuba ${ }^{99}$, jak też w kościele dominikańskim w Oświęcimiu, jest spowodowany, jak sądzę, niedostatkiem kwerendy.

W krakowskim kościele franciszkanów pierwszym znanym nam organistą był wzmiankowany w 1445 r. brat Stanisław ${ }^{60}$. Czas wybudowania tam organów możemy wyznaczyć szeroko na okres przed 1445 rokiem. Pracę przy organach dla kościoła św. Franciszka wykonał w I463 r. organmistrz katedralny Jerzy, syn szewca Jerzego z Krakowa. Ojciec organmistrza domagał się od gwardiana Mikołaja zapłaty 4 grzywien $^{61}$. Znamy jednak również przynajmniej dwóch franciszkanów-organmistrzów. W I490 r. brat Wolfgang z krakowskiego klasztoru franciszkanów wybudował organy

52 Kodeks dyplomatyczny katedry krakowskiej św. Wactawa, t. I-2, wyd. Franciszek Piekosiński, Kraków I874-83, t. 2 , nr 525 .

53 A. Chybiński, op. cit., s. 48, 52, 54, 62, IO2; J. Mizgalski, op. cit., s. 8I. W literaturze naukowej poświęconej dominikanom, bardzo obfitej, nie podejmowano tematu ich wkładu do kultury organowej, zob.: Paweł Kielar, „Studia nad kulturą szkolną i intelektualną dominikanów prowincji polskiej w średniowieczu”, w: Studia nad historia dominikanów w Polsce (I222-1972), red. Jerzy Kłoczowski, t. I, Warszawa 1975, s. 27I-516; Mendykanci w średniowiecznym Krakowie, red. Krzysztof Ożóg, Tomasz Gałuszka OP, Anna Zajchowska, Kraków 2008. AKM, Off. 88, s. 289 i nast.

55 Feliks Kiryk, Franciszek Leśniak, „Mieszkańcy”, w: Dzieje Sandomierza, t. 2, red. Feliks Kiryk, Warszawa I993, s. 23939.

56 W. Kapeć, op. cit., s. 55; tegoż, „Życie muzyczne w lubelskim klasztorze dominikanów”, w: Dominikanie w Lublinie. Studia z dziejów i kultury, red. Henryk Gapski, Lublin 2006, s. 219-237; Ludwik Gawroński, Muzyka religijna w Lublinie, Lublin 1996, s. 231. Wiktor Łyjak („Organy i dokumenty na temat organów dominikańskich”, op. cit., s. 707) wspomina dopiero o organach z XVII w., które reperowano w I7I7 roku. AKM, AVCap. 2, k. I32; AVCap. 7, k. I2I.

58 W. Kapeć, Organy i organiści, op. cit., s. 44.

59 Ibid., s. 6I.

60 ZDM 3, nr 725; Wiktor Łyjak („Organy w kościoła franciszkanów konwentualnych”, op. cit., s. 289) przytacza, jako najstarszą, wzmiankę z I488 roku.

6I CASupp. I462-75, nr I3; AKM, Off. I2, s. I83 O zakresie prac wypowiedziano się bardzo ogólnikowo: „racione laboris organorum”. 
w Zatorze ${ }^{62}$. W 1518 r. franciszkanin Jakub skonstruował organy w kaplicy Mariackiej katedry krakowskiej. Przy tej okazji dowiadujemy się, że jako środek pomocniczy dano mu stare organy. Kontrakt zawierał nawet taki szczegót, że jeden głos miał być gotowy na św. Michała, pozostałe wraz z całością na św. Marcina ${ }^{63}$. Wzmianki te stanowią znakomite świadectwo, że posiadający własny warsztat klasztor franciszkański wykonywał prace dla innych kościołów, ale także korzystał z doświadczenia innych organmistrzów.

Z późniejszych źródeł wynika, że w 1576 r. w kościele franciszkanów były dwa instrumenty, a protokół powizytacyjny z końca XVI w. odnotowuje pozytywy w każdej z czterech kaplic przy kościele ${ }^{64}$. Ze wzmianki z I584 r. wiadomo, że organista Stanisław mieszkał nad kaplicą Węgierską, a od I58I r. organiście wypłacano stałą pensję̧5. Organy w kościołach franciszkańskich w Nowym Sączu i Nowym Korczynie są poświadczone w pierwszej ćwierci XVII w. ${ }^{66}$. Można przypuszczać, że organy te istniały już w XVI wieku. Nie mamy danych o instrumentach muzycznych w kościołach franciszkańskich w Radomiu i Lelowie.

Klasztorem o wybijającej się kulturze muzycznej byli augustianie przy kościele św. Katarzyny na Kazimierzu. Fakt ten podkreśla się zarówno w literaturze historycznej, jak i muzykologicznej ${ }^{67}$. Można przypuszczać, że organy w kościele św. Katarzyny brzmiały już $\mathrm{w}$ drugiej połowie XIV w., jednakże poświadczenie ich istnienia jest stosunkowo późne. W I436 r. wzmiankowany jest organista Andrzej ${ }^{68}$. W literaturze za pierwszych organistów tego kościoła uważa się dopiero występujących w 1. I470 i I47I Bernarda i Błażeja ${ }^{69}$. Wzmianka z I436 r. pozwala na znacznie wcześniejsze datowanie istnienia instrumentu. Występowanie Bernarda i Błażeja w tym samym

62 AKM, Off. II, k. 338v; B. Przybyszewski, Krakowskie środowisko artystyczne, op. cit., s. I87.

63 AKM, Off. 44, s. 24.

64 Tadeusz Maciejewski, „Kultura muzyczna franciszkanów konwentualnych w świetle wizytacji O.G. Caputo i kilku innych źródeł z początku XVII wieku”, w: Zakony franciszkańskie w Polsce, red. Jerzy Kłoczowski, t. 2, Franciszkanie w Polsce XVI-XVIII wieku, cz. 2, Niepokalanów 2003, s. 23I-265, o pozytywach w kaplicach na s. 245. Ogólnie o wyposażeniu kościołów franciszkańskich w organy pisał Kamil Kantak (Franciszkanie polscy, t. 2, Kraków 1938, s. 246), ale przytaczane przez niego przykłady pochodzą dopiero z XVII w., zob. także: W.Z. Łyjak, „Organy w kościołach franciszkanów konwentualnych”, op. cit., s. 290.

65 T. Maciejewski, op. cit., s. 245.

66 Ibid., s. 246-247.

67 Niezwykle rzetelnie, na tle kultury i sztuki klasztoru augustiańskiego, ukazała to Barbara Frydrychowicz w artykule „Augustiański fragment organowy i jego środowisko macierzyste”, (Muzyka I6 (I97I) nr 2, s. 3-33); nie zmieniła tej wysokiej oceny polemika Mirosława Perza „Na marginesie pracy Barbary Frydrychowicz Augustiański fragment organowy i jego środowisko macierzyste" (Muzyka I7 (I972) nr 2, s. IOI-IO3). W literaturze mediewistycznej zagadnienie roli augustianów w kulturze muzycznej podjął Wacław Kolak, Klasztor augustiański przy kościele św. Katarzyny w Krakowie do potowy XVI wieku. Fundacja, rozwój uposażenia i rola kulturalna, Kraków 1982.

68 AKM, Off. 5, k. I9I.

69 W. Kolak, op. cit., s. Io6; Barbara Frydrychowicz (op. cit., s. 9) wymieniła tylko organistę Bernarda, pomijając Błażeja. Ernest Kubala („Historia organów w kościele p.w. św. Katarzyny w Krakowie”, w: Organy i muzyka organowa, t. 7, Gdańsk 1988, s. 4I-46) pierwszą wzmiankę o organach datuje dopiero na I490 rok. 
mniej więcej czasie dowodzi słuszności wysuwanej w literaturze tezy, że w kościele tym były organy główne, używane w liturgii dla parafian, oraz organy chóru zakonnego $^{70}$. W świetle ustaleń literatury można przyjąć, że organy funkcjonowały nieprzerwanie od drugiej połowy XV w. ${ }^{71}$. Jakub „de Santo Francisco” w 1. I522-38 wybudował „wielkie organy” na ścianie bocznej nawy głównej, które spłonęły w I556 r.72. Warto zwrócić uwagę, że ów włoski organmistrz wznosił swoje dzieło, gdy przeorem u św. Katarzyny był inny Włoch - Florian „de Monte Reggio”73. Na okres ich działalności przypada powstanie w klasztorze św. Katarzyny utworu organowego, będącego najstarszym znanym obecnie polskim utworem muzycznym wykonywanym na organach. Przetrwał bowiem jego fragment, który spisany został na desce, stanowiącej pierwotnie prawdopodobnie fragment pulpitu organowego, zaś graduał, w którym ten fragment się znajduje, ukończony został w I528 roku. Utwór, spisany w notacji staroniemieckiej, Barbara Frydrychowicz identyfikuje jako niezwykle popularną sekwencję na święto Wniebowzięcia Najświętszej Marii Panny74. Z XV-XVI w. znani są w kościele św. Katarzyny organiści Marcin, Mateusz, Paweł i Baltazar ${ }^{75}$. W Książu Wielkim organista Jan jest poświadczony w I45I r., ale nie wiemy, czy jest to organista klasztorny ${ }^{76}$, bowiem w tym mieście osobno istniał kościół parafialny. Z I494 r. pochodzi wzmianka o Janie z Kromołowa, organiście w klasztorze augustianów w Olkuszu, filii kazimierskiego konwentu77. Nie mamy natomiast wystarczających źródeł dla kwestii wyposażenia kościoła augustianów w Pilznie. Generalnie jednak znaczenie augustianów w rozwoju organów małopolskich można określić jako wybitne.

Najmłodszym w rodzinie z zakonów żebrzących był zakon bernardynów. Kościół bernardynów na Stradomiu pod Krakowem został ufundowany w I454 roku. Wiktor Łyjak stwierdza, że najstarsze wzmianki o organach w kościołach bernardyńskich pochodzą dopiero z końca XVI w., co autor wiąże z istnieniem „obostrzeń w tym względzie”, bliżej jednak ewentualnych zakazów reguły nie wyjaśnia ${ }^{78}$. Adolf Chy-

O trzech instrumentach pisała Frydrychowicz, op. cit., s. 9; W. Kolak, op. cit., s. Io6.

Ernest Kubala (op. cit., s. 4I-46) twierdzi, że organy w tym kościele są odnotowywane w I490, I507, I509 i I 5 IO r., nie podał jednak źródła tych informacji.

Ibid., s. 4I-46.

Włodzimierz Zega, „Rękopisy średniowieczne z klasztoru augustianów eremitów na krakowskim Kazimierzu", w: Mendykanci w średniowiecznym Krakowie, op. cit., s. I78-179.

B. Frydrychowicz, op. cit., s. I7.

Ibid., s. 9; J. Mizgalski, op. cit., s. 8I; W. Kolak, op. cit., s. 98, Io6; AKM, Off. 62, s. 39.

AKM, Off. I, s. I90. Eugeniusz Madejski („Klasztor augustianów w Książu Wielkim”, Analecta Cracoviensia 2I/22 (1989/1990), s. 398) pisze o dziesięciogłosowym pozytywie ufundowanym w I75I roku.

AKM, Off. I8, k. 307. Organy w tym kościele poświadcza także protokół z wizytacji biskupa Maciejewskiego, Archiwum Krakowskiej Kapituły Katedralnej, rps AVis. I8, k. 23 I.

8 W. Łyjak, „Budownictwo organowe w zakonie bernardynów”, op. cit., s. 208. Z kolei Wiesław F. Murawiec (Bernardyni warszawscy I454-I864, Kraków I973, s. 32) podaje, że „jeszcze w I599 r. kapituła prowincjonalna wykluczyła wprowadzanie wszelkich instrumentów do kościołów prowincji wielkopolskiej, aczkolwiek wydaje się, że nie dotyczyło to organów”. W pracach historyków zagadnienia tego w ogóle nie podjęto, zob. np.: Małgorzata Maciszewska, Klasztor bernardyński w spoteczeństwie polskim I453-I530, Warszawa 200I, 
biński podał, że bernardyn Stanisław Przemowa rzeźbił prospekt organowy w stradomskim kościele w 1606 r. ${ }^{79}$. Natomiast Jerzy Mizgalski uważał za pierwszego stradomskiego organistę Jana, zmarłego w I60I r. ${ }^{80}$. Wskazywać by to mogło na istnienie organów najpóźniej pod koniec XVI wieku. Inni autorzy, nie odnosząc się do datacji podanej przez Chybińskiego, piszą, że Przemowa prowadził przebudowę na Stradomiu w l. 1645-47 i „w kościele dodano wtedy nowe organy”. Równocześnie podają, że Stanisław Przemowa w Przeworsku wykonał pod koniec XVI w. ołtarz i ambonę ${ }^{8 I}$. Kwestia ta powinna być w dalszych badaniach zweryfikowana. Nie mamy także danych o organach w kościołach bernardyńskich w Tarnowie i Opatowie ${ }^{82}$.

Kwestie związane z regułą pojawiają się także u paulinów i cystersów. Pierwsza wzmianka o organiście Aleksym w kościele paulińskim na Skałce pochodzi z 1475 r. ${ }^{83}$, co oznacza, że już w trzy lata po fundacji klasztoru paulińskiego był w kościele skałecznym instrument muzyczny. Z I538 r. pochodzi zapiska o zapłacie za ołów na organy w kościele na Skałce ${ }^{84}$, co oznacza, że stary instrument był zapewne remontowany. W I54I r. wzmiankowany jest paulin Stanisław Nogietek, niegdyś organista na Skałce ${ }^{85}$. Z I554 r. pochodzi wzmianka o nieżyjącym już wówczas organiście Wawrzyńcu ${ }^{86}$. Mimo istnienia prac szczegółowych na temat organów skałecznych, wzmianki te nie są znane $\mathrm{w}$ dotychczasowej literaturze ${ }^{87}$. Klasztor paulinów istniał także, od I449 r., w Pińczowie. Paulini byli w XVI w. pozbawiani swego kościoła przez innowierców, ale za każdym razem powracali. Pod koniec XVI w. są w tym kościele wzmiankowane organy, a muzyk był uposażony z dochodów konwentu ${ }^{88}$. W I6I8 r. wśród kapłanów przy pińczowskim kościele paulinów odnotowany został „Adam Częstochowiensis organista”, a zatem paulin z Częstochowy, posiadający

s. II9 i I68; Jakub Kostowski, „Świątynie klasztorne bernardynów jako wyraz idei Kościoła Walczącego i Triumfującego. Ich architektura i wyposażenie", w: Ecclesia et civitas. Kościót i życie religijne $w$ mieście średniowiecznym, red. Halina Manikowska, Hanna Zaremska, Warszawa 2002, s. 8I-IO2.

79 A. Chybiński, op. cit., s. I03; J. Gołos, Polish organ, op. cit., s. 259.

8 o J. Mizgalski, op. cit., s. 8I.

8I Klasztory bernardyńskie $w$ Polsce $w$ jej granicach historycznych, red. Hieronim Eugeniusz Wyczawski, Kalwaria Zebrzydowska 1985, s. $155,280$.

82 Franciszek Rydzak, Bernardyni w Tarnowie, Tarnów 2007, s. 3I-32; Radosław Kubicki, „Konwent bernardynów w Opatowie w XV-XVIII wieku. Wybrane zagadnienia społeczno-gospodarcze”, w: W stużbie Bogu i spoteczeństwu. Zakony na ziemiach polskich w XVI-XIX wieku, red. Dariusz Kupisz, Radom 2004, s. 19-30.

83 CASupp. I462-75, nr 255; AKM, Off. 2, s. 223.

84 AKM, Acta Administroralia 2, k. 317.

85 AKM, Off, 7I, k. 445.

86 AKM, Off. 73 , s. 658.

87 Jacek Kulig („Organy kościoła na Skałce - historia i teraźniejszośc”, Peregrinus Cracoviensis I4 (2003), s. 175-I87) rys historyczny organów w tym kościele rozpoczyna dopiero od I76I r., opisuje także przeróbki instrumentu, który przetrwał do dziś; tylko o obecnie istniejącym instrumencie pisze Piotr Matoga („Organy w bazylice Paulinów na Skałce w Krakowie”, Studia Claromontana 29 (20II), s. 507-585).

88 AKM, AVCap. Io, k. 5ov, 52. Losy klasztoru ukazał Janusz Zbudniewek („Klasztor paulinów w Pińczowie”, w: Pińczów za panowania pińczowskiej linii Oleśnickich. Materiaty sesji naukowej 24 lutego $1997 \mathrm{r}$., red. Agnieszka Kwiecień, Krzysztof Słonina, Andrzej Grygiel, Pińczów 1997, s. I6-43), w pracy nie porusza on jednak kwestii organów.

89 AKM, AVCap. 38, s. 6I. 
wykształcenie muzyczne. Jest to informacja niezwykle ważna z uwagi na brak wyrazistych wzmianek odnoszących się do klasztoru macierzystego zakonu paulinów, czyli do Jasnej Góry. W I489 r. odnotowany został Stefan, organista z Częstochowy, przy okazji pewnej sprawy sądowej, jaką toczył z Walentym, organistą z Krakowa ${ }^{90}$. Pod koniec XVI w. organy znajdowały się na pewno w kościele św. Zygmunta, parafii miejskiej, ale administrowanej przez przeora paulińskiego, co pozwala przypuszczać, że ów Stefan był organistą w miejskim kościele parafialnym św. Zygmunta. Z faktu, że w XV w. grały organy na Skałce, w XVI w. także w Pińczowie, nie możemy czerpać analogii do Jasnej Góry. Pamiętać bowiem musimy, że kościoły paulińskie na Skałce i w Pińczowie były zarazem świątyniami parafialnymi i ten fakt zapewne zadecydował o wczesnym instalowaniu w nich organów. Rozróżniać bowiem należy, nie tylko w przypadku paulinów, kościoły klasztorne-konwentualne i klasztorne-parafialne. Kościół jasnogórski, będący świątynią konwentualną, odgrywał jednak wyjątkową rolę także jako ośrodek pielgrzymkowy. Powodowało to rozmaite trudności, np. pod koniec XVI w. uciążliwe dla paulinów było zajmowanie przez pielgrzymów stall zakonnych w prezbiterium. Dla tłumów pątników piękna oprawa muzyczna nabożeństw niewątpliwie podnosiłaby atrakcyjność świętego miejsca, a z drugiej zaś strony surowość reguły zakonnej mogła stawać temu na przekór. Nie posiadamy żadnych wcześniejszych niż z XVII w. informacji o organach w kościele jasnogórskim ${ }^{91}$.

Spróbujmy prześledzić tę kwestię u innych rygorystów, a mianowicie u cystersów. Z badań Jamesa France’a wynika, że do I486 r. nie wolno było w zakonie cysterskim instalować i używać organów ${ }^{92}$. Z okresu do 1486 r., a także kilkudziesięciu lat później, brak jakichkolwiek wiadomości o organach w małopolskich kościołach cysterskich. Z zezwolenia kapituły generalnej na instalację organów małopolscy cystersi skorzystali, co trzeba podkreślić, dopiero po około czterdziestu latach. Duże znaczenie ma tutaj, jak sądzę, uzyskanie uchylenia klauzury w I530 lub I540 r. w opactwie mogilskim za Erazma Ciołka, co skutkowało przyjmowaniem wiernych w kościele klasztornym ${ }^{93}$. W rękopiśmiennych Żywotach opatów mogilskich czytamy, że właśnie opat Erazm Ciołek (w l. I522-46) zbudował organy w kościele klasztornym ${ }^{94}$.

90 AKM, Off. in, k. 287v.

9I Janusz Zbudniewek, „Klasztor jasnogórski i jego rola pielgrzymkowa”, w: Częstochowa. Dzieje miasta $i$ klasztoru jasnogórskiego, t. I, red. Feliks Kiryk, Częstochowa 2002, s. 394; tegoż, „Paulini na przełomie XIV i XV wieku", w: Ksiązę Wtadystaw Opolczyk [ok. I326-I40I] fundator klasztoru Paulinów na Jasnej Górze w Częstochowie, red. Marceli Antoniewicz, Janusz Zbudniewek, Warszawa 2007, s. II9-I78. W problematykę obecnie istniejącego instrumentu wprowadza Jerzy Gołos, „Organy A.H. Caspariniego na Jasnej Górze”, Studia Claromontana I (198I), s. 2II-216; Wiktor Z. Łyjak, „Adam Orazio Casparini i jego jasnogórskie dzieła", Studia Claromontana 20 (2002), s. I4I-I92.

92 James France, Cistercians in medieval art, Kalamazoo, Mich. 1998, s. I73.

93 Marcin Starzyński, Maciej Zdanek, „Mogiła w czasach Stanisława Samostrzelnika - szkic do dziejów klasztoru na przełomie XV i XVI w.", Cistercium Mater Nostra I (2007), s. 44; Paweł Szywalski, "Osiemnastowieczne zbiory muzyczne Archiwum klasztoru mogilskiego (kontekst historyczny)”, Nasza Przesztość II2 (2009), s. 236.

94 Biblioteka Książąt Czartoryskich w Krakowie, rps 3062 IV, s. 47; rps 3652 III, s. 50. 
Informacja ta jest w pełni wiarygodna, czego dowodzi wzmianka z I54I r. o Adamie organiście i podprzeorze mogilskim ${ }^{95}$. Z drugiej połowy XVI w. pochodzi zapiska o organiście mogilskim Janie, cystersie z pięćdziesięciopięcioletnim stażem w zakonie ${ }^{96}$. Tadeusz Maciejewski przytoczył ponadto informacje o organistach-mnichach Benedykcie, zmarłym w 1575 r., i Teodorze Kocielowskim, zmarłym w I597 r. ${ }^{97}$.

Analiza księgi zmarłych opactwa cystersów w Jędrzejowie pozwala stwierdzić, że przed 1573 r. działał mnich Albert organista ${ }^{98}$. Jest to najstarsza wzmianka w interesującej nas kwestii w odniesieniu do Jędrzejowa. W ostatniej ćwierci XVI w. w nekrologu jędrzejowskim wzmiankowani są Wawrzyniec „organista famulus noster” oraz Klemens „organista tego domu”. Pierwszy z nich to bliżej nieznany sługa klasztorny, drugi to zapewne cysters' ${ }^{99}$. Wzmianki te dotyczą, co należy mocno podkreślić, świątyni konwentualnej. Gdy wizytowano pod koniec XVI w. parafię miejską w Jędrzejowie, będącą pod zarządem cystersów, wykazano w kościele organy, rektora szkoły i kantora, uposażonych częściowo przez rajców - organistą był zapewne rektor lub kantor ${ }^{\mathrm{IOO}}$. W kościele cysterskim w Szczyrzycu organy zostały odnotowane po raz pierwszy dopiero w I597 $\mathrm{r}^{\text {IOI }}$. Na podstawie tych trzech przykładów można stwierdzić, że organy w kościołach cysterskich zaczęto budować dopiero w pierwszej połowie XVI wieku. Brak jest, na razie, wczesnych danych źródłowych co do organów w kościele cysterskim w Wąchocku. Małgorzata Borkowska pisze, że zapewne w I659 r. „powstały zachowane do dzisiaj organy o trójwieżowym, bardzo pięknym prospekcie”. Z jej ustaleń wynika, że jest to najwcześniejsza wzmianka o organach w kościele cystersów w Wąchocku ${ }^{\mathrm{IO} 2}$. Nie mamy także żadnych wczesnych informacji o organach w kościele cysterskim w Koprzywnicy, skądinąd bardzo znaczącym jeśli idzie o cysterskie organmistrzostwo w Polsce ${ }^{\mathrm{IO} 3}$.

95 Kazimierz Łatak, „Cystersi mogilscy w nekrologu krakowskiego klasztoru kanoników regularnych laterańskich. Uwagi do dziejów konfraterni”, Nasza Przesztosśc 90 (1998), s. 463. Mocno spóźnioną datację dotyczącą powstania organów - rok 1575 - podaje Jerzy Gołos (The Polish organ, op. cit., s. 346).

96 K. Łatak, „Cystersi mogilscy w nekrologu krakowskiego klasztoru”, op. cit., s. 463.

97 T. Maciejewski, op. cit., s. 652. Teodor „organarius de Clara Tumba” został odnotowany w nekrologu opactwa cysterskiego w Lądzie, MPH 5, s. 494.

98 Liber mortuorum monasterii Andreoviensis Ordinis Cisterciensis, wyd. Wojciech Kętrzyński, Monumenta Poloniae Historica, t. 5, Lwów I888, s. 775.

99 Ibid., s. 78I.

I0о AKM, AVCap. Io, k. 95.

IoI AKM, AVCap. 9, s. 82.

IO2 Małgorzata Borkowska, $Z$ dziejów opactwa cystersów w Wąchocku, Kielce I998, s. II7-II8. Wiktor Łyjak („Organowe dziedzictwo cystersów w Polsce”, op. cit., s. 204, 24I) pisze o dwóch instrumentach w kościele pocysterskim w Wąchocku - osiemnastowiecznym sześciogłosowym pozytywie w transepcie i starszych organach nad głównym wejściem. Te drugie uznaje za „najcenniejszy zabytek organowego budownictwa cysterskiego w Polsce”. Zob. także: Marian Dorawa, „Problematyka konserwatorska i wartości głównych organów kościoła klasztornego oo. cystersów w Wąchocku”, w: Organy i muzyka organowa, t. 2, Gdańsk I978, s. 89-104.

I03 Wiktor Łyjak („Organowe dziedzictwo cystersów w Polsce”, op. cit., s. 205) przytacza informację z 1764 r. o dwunastogłosowych organach w kościele cysterskim. 
Jeśli zatem u cystersów i paulinów hamującą rolę w instalowaniu organów odegrała reguła, to przykład kościoła karmelitów na Garbarach pod Krakowem, zakonu o bardzo surowej regule, wskazuje na inne zjawisko, a mianowicie bardzo wczesne wybudowanie organów w świątyni konwentualnej. Kościół ten, ufundowany w 1397 r., posiadał organy niewątpliwie już w pierwszej połowie XV w., gdyż z I450 r. znany jest organista Wacław ${ }^{104}$. W I 480 r. poświadczono na tej funkcji Mikołaja ${ }^{\text {Ios. }}$ Z I494 r. pochodzi wiadomość, że przeor Marcin miał wypłacić organmistrzowi Stefanowi Rothoze z Przemyśla ostatnią ratę za ukończenie budowy nowego instrumentu. Do jego odbioru zaproszono Jana z Łużyc, organistę kościoła Mariackiego ${ }^{\mathrm{I0}}$. $\mathrm{Na}$ marginesie wskażemy, że wzmianka ta ukazuje korzystanie przez karmelitów z dorobku różnych środowisk organmistrzowskich. Ważniejsza wydaje się kwestia przyczyn tak wczesnego podjęcia budowy organów w tym kościele. Domyślać się jedynie możemy, że karmelitom zależeć mogło na muzycznej oprawie liturgii maryjnej, związanej z miejscowym obrazem, obiektem kultu ludności Krakowa i przedmieść. Nie mamy natomiast danych o organach w kościele karmelitów w Jaśle.

Odrębnym zagadnieniem są organy w kościołach żeńskich klasztorów klauzurowych. Jest ono interesujące chociażby z tego powodu, że na pewno nie wchodziły w grę potrzeby liturgii dla wiernych, a ponadto obecność mężczyzny-organisty w żeńskim kościele konwentualnym budziła spore kontrowersje. Muzyk ten akompaniował liturgii zakonnej, a także, jak wskazują przykłady późniejsze, uczył zakonnice śpiewu ${ }^{\text {107. }}$ Krakowski kościół św. Andrzeja, należący do klarysek, posiadał organy najpóźniej w połowie XV w. ${ }^{108}$. Obecność organisty, Piotra z Szumarska, zarazem kapelana katedralnego, poświadczona jest już w I455 roku. Grał w kościele klarysek

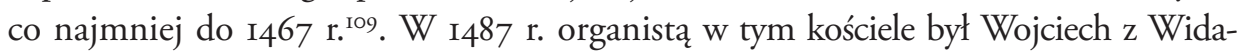
wy ${ }^{\text {IIO }}$ W I526 r. została poświadczona obecność Andrzeja, niegdyś organisty w kościele klarysek $^{\text {III }}$. W protokole powizytacyjnym z końca XVI w. odnotowano, że w kościele św. Andrzeja jest zarówno organista, jak i kalikant. Zalecono, aby obok organów postawić

IO4 Cracovia artificum supplementa. Teksty źródtowe do dziejów kultury i sztuki z archiwaliów kurialnych $i$ kapitulnych w Krakowie I44I-I450, opr. Bolesław Przybyszewski, Kraków 1993, nr 585.

IO5 AKM, Off. II, s. 745; zapiskę tę cytuje Piotr Matoga, Organy w bazylice oo. karmelitów na Piasku w Krakowie, Lublin 20I4, s. II.

I06 AKM, Off. 24, s. 355, 369, 397; P. Matoga, op. cit., s. II.

IO7 Można przytoczyć wzmiankę z 1759 r., mówiącą, że klaryski sądeckie uczą się muzyki u organisty; AKM, Acta Episcopalia Cracoviensia, t. 98, s. 90.

Io8 Piotr Matoga, „Historia organów w najstarszych polskich klasztorach sióstr klarysek”, Nasza Przesztość I22 (20I4), s. 54.

I09 Cracovia artificum supplementa. Teksty źródtowe do dziejów kultury i sztuki z archiwaliów kurialnych $i$ kapitulnych $w$ Krakowie I45I-I460, opr. Bolesław Przybyszewski, Kraków 200I, nr 222, 264, 3II, 329, 400, 40I; Cracovia artificum supplementa I462-I475, opr. Bolesław Przybyszewski, Kraków 2000, nr 3I, 36, 84, AKM, Off. IO, s. 23, 67, I74, 333, 439; Off. 9, s. 916.

IIO AKM, Off. I5, s. 325 .

III Wypisy źródtowe do dziejów Wawelu Is26-29 (zob. przyp. I4), s. I35-I36. 
wysoką deskę, aby organista nie miał możliwości patrzenia na chór zakonnic ${ }^{\mathrm{II} 2}$. W XV w. istniały organy w kościele norbertanek na Zwierzyńcu, o czym świadczą organiści Marcin i Jakub wspomniani w średniowiecznej partii nekrologu, organista Mateusz wzmiankowany w I5O2 r. i organista Wojciech odnotowany w I5I2 r. ${ }^{\mathrm{II} 3}$. Istotną przesłanką wskazującą na istnienie organów w kościele norbertanek w Imbramowicach jest zapiska z I45O r. mówiąca, że Mikołaj, premonstratens przy tym klasztorze, zobowiązał się do wypłacenia I4 groszy Wacławowi, organiście kościoła karmelitów na Piasku ${ }^{\mathrm{II} 4}$. O organach w kościele norbertanek w Krzyżanowicach przygodnie informuje zapiska z I6I8 r. ${ }^{\text {II }}$. Jak wiadomo, najstarszy małopolski klasztor klarysek w Starym Sączu był promieniującym ośrodkiem kultury muzycznej, posiadającym w swej bibliotece dzieła paryskiej szkoły Notre Dame z XIII w. ${ }^{\text {II6 }}$. Nie można wykluczyć, że organy były w Starym Sączu od dawna. Gdy napotykamy na wzmiankę o organistach piszących się „de Sandecz”, nie zawsze da się określić, którego kościoła one dotyczą ${ }^{\mathrm{II}}$. W I568 r. poświadczony jest Feliks Swieszkowicz, organista klasztoru w Starym Sączu ${ }^{\mathrm{II} 8}$ i jest to pierwsza niebudząca wątpliwości informacja o organach w kościele klarysek starosądeckich. O organiście Jakubie Sherperze i organach czytamy następnie w protokole powizytacyjnym z końca XVI w. ${ }^{\text {II }}$. Podobnie jak w przypadku klarysek krakowskich, tak i w Starym Sączu, wizytator biskupi zalecił odgrodzenie organisty parawanem z desek, aby nie mógł on spoglądać na chór zakonnic ${ }^{\mathrm{I} 20}$. W kolejnym protokole z I6I8 r. pisze się o organach „starych” w kościele klarysek co, moim zdaniem, odnosi się do organów funkcjonujących najpóźniej w XVI w. ${ }^{\mathrm{I2I}}$. Jeśli idzie o klasztor benedyktynek w Staniątkach, to zachowała się wzmianka z I464 r. poświadczająca, że Marek, organista z Brzeska, świadczył klasztorowi jakieś usługi i z tego tytułu klasztor winien mu był 9 grzywien ${ }^{\text {I22 }}$. Niezwykle wysoka kwota i profesja tegoż Marka przekonują, że chodziło o prace przy organach w kościele benedyktynek. W I52I r. poświadczony został Stanisław z Krakowa, organista w kościele w Staniątkach ${ }^{\mathrm{I2} 3}$. Do grupy klasztorów o starych organach zaliczyć można jeszcze kościół

II2 AKM, AVCap. 9, s. 35.

II3 Jerzy Rajman, „Średniowieczne zapiski w nekrologu klasztoru norbertanek na Zwierzyńcu”, Nasza Przesztość 77 (1992), s. 39, 45, 47; AKM, Off. 21, k. I6I; Off. 36, k. 31.

II4 AKM, Off. 9, s. 44.

IIs AKM, AVCap. 38, s. 7I.

II6 Mirosław Perz, „Organum, conductus i średniowieczny motet w Polsce. Źródła i problemy”, Muzyka I8 (1973) $\mathrm{nr}$ 4, s. 3-II.

II7 Np. w I465 r. występuje Piotr organista „de Sandecz”, Cracovia artificum Supplementa I462-I475, op. cit., nr 45; Wacław Urban, Dwa szkice z dziejów Reformacji, Kielce I99I, s. 4I. Na kartach księgi miejskiej Nowego Sącza organiści występują jako „de Sandecz”, ale ze względu na proweniencję źródła można ich identyfikować z muzykami miejskimi z kościoła św. Małgorzaty.

II8 AKM, Off. I05, s. 690, 880.

II9 AKM, Acta Visitationis 2 (cyt. dalej AV 2), k. Io2.

I20 P. Matoga, „Historia organów w najstarszych polskich klasztorach sióstr klarysek”, op. cit., s. 35.

I2I Jan Chwałek, „Postanowienia strony robienia organ (umowa z I6I8 r. na budowę organów w kościele klarysek w Starym Sączu)", Studia Organologica 2 (1998), s. 7-3I.

I22 Cracovia artificum supplementa I462-I475, op. cit., nr 42; AKM, Off. I2, s. 397.

I23 AKM, Off. 39, s. 709. 
św. Brygidy zakonu brygidek w Lublinie, gdzie kapłan-organista poświadczony został pod koniec XVI w. ${ }^{124}$. Nie mamy natomiast informacji o organach w kościele bernardynek na Stradomiu.

Zachowało się sporo danych o miejscu usytuowania organów w kościele. Instrument zbudowany w XIV w. w kościele Bożego Ciała znajdował się w prezbiterium przy bocznej ścianie od strony północnej. Można było do niego dotrzeć krętymi schodami ${ }^{125}$. U dominikanów lubelskich organy miały być „na prawej ścianie prezbiterium" ${ }^{226}$. W kościele dominikańskim w Krakowie inwentarz z 1. I820-22 opisuje „organ staroświecki w środku kościoła pod samem sklepieniem, jakoby w powietrzu zawieszony. Chór z drzewa sosnowego bez żadnych ozdób, malowany. Tylko wchód na tenże z korytarza klasztornego przez strych kościelny...”. Opis ten dotyczy instrumentu z pierwszej połowy XVI w. ${ }^{\mathrm{I} 7}$. Co ciekawe, relikty klatki schodowej prowadzącej na strych zachowały się do dziś w kościele franciszkańskim w Krakowie ${ }^{128}$. Jedynym sposobem dostania się do organów zamocowanych wysoko pod sklepieniem było przejście przez strych nad sklepieniem. Organy w kościele klasztornym w Szczyrzycu odnotowano jako usytuowane nad ołtarzem Narodzenia Najświętszej Marii Panny ${ }^{129}$. Wydaje mi się, że chodzi tu o któryś z ołtarzy bocznych w nawie głównej. Gdy w 1742 r. organmistrz Jan Sadowski odnawiał i reperował „stare organki” w kościele w Szczyrzycu, zamierzał „klawiaturę obrócić, aby była dla organisty twarzą do ołtarza wielkiego"130. Remontowi był poddany, jak sądzę, właśnie stary instrument nad ołtarzem, istniejący pod koniec XVI wieku. W przypadku dominikanów krakowskich i kościoła cysterskiego w Szczyrzycu mamy poświadczone zawieszenie organów bardzo wysoko, pod sklepieniem, w czym dostrzegamy realizację rozpowszechnionego na Zachodzie modelu ,jaskółczego gniazda”. Z cytowanego wyżej opisu organów dominikańskich „pod sklepieniem” wiadomo, że piszczałki z nich wykorzystano w budowie instrumentu nad głównym wejściem. Organy Józefa z Sochaczewa (I544 r.) stanowią najstarszy przykład usytuowania instrumentu organów nad głównym wejściem ${ }^{131}$.

I24 AKM, AV 2, k. I60-193, k. I63; o organach lubelskich zob.: Waldemar Kapeć, Tajemnice lubelskich organów, Lublin 2009; zagadnienia związane z historią organów lubelskich porusza L. Gawroński, op. cit. (zob. przyp. 56), s. 3I-35, 4I-44, 48-52, 59-63, 70-74.

I25 K. Łatak, Kanonicy regularni laterańscy, op. cit., s. II8.

I26 W. Kapeć, Organy i organiści, op. cit., s. 55; tegoż, „Życie muzyczne w lubelskim klasztorze dominikanów”, op. cit., s. 219-237; L. Gawroński, op. cit., s. 23I. Wiktor Łyjak („Organy i dokumenty na temat organów dominikańskich", op. cit., s. 707) wspomina dopiero o organach z XVII w., które reperowano w I717 roku.

I27 W. Kapeć, Organy i organiści, op. cit., s. 39.

I28 Waldemar Niewalda, Halina Rojkowska, „Średniowieczny kościół franciszkanów w świetle ostatnich badań", w: Mendykanci wśredniowiecznym Krakowie, op. cit., s. 28I.

I29 AKM, AVCap. 9, s. 82-84.

I30 Jolanta M. Marszalska, Waldemar Graczyk, Opaci i przeorzy opactwa cystersów w Szczyrzycu od XIII do XX wieku, Kraków-Tyniec 2006, s. 157.

I3I W. Kapeć, Organy i organiści, op. cit., s. I08; Jarosław Kisieliński, „Lokalizacja organów w świetle tradycji i dokumentów Kościoła”, w: Artificium Ars Scientia, Ksiegga Jubileuszowa w 8o. rocznicę urodzin Ks. Profesora Jana Chwatka, red. Maria Szymanowicz, Lublin 2010, s. 397-4IO. 
O technicznej stronie organów klasztornych mamy garść cennych informacji. Wychodząc z przesłanek ogólnych stwierdzić najpierw należy, że zarówno zaginiona tabulatura klasztoru św. Ducha w Krakowie, jak i tabulatura Jana z Lublina zawierają szereg utworów, które były wykonywane z użyciem klawiatury nożnej ${ }^{132}$. Bezpośrednie poświadczenie istnienia pedału mamy w przypadku organów z I 534 r. w krakowskim kościele dominikanów. W klawiaturę nożną z pewnością były wyposażone organy w kościele Grobu Bożego w Miechowie. Historyk miechowski Samuel Nakielski, bożogrobiec publikujący dzieła historyczne w pierwszej połowie XVII w., powtórzył informację o wybudowaniu w 1376 r. organów, dodając, że posiadały one dwadzieścia dwa głosy ${ }^{133}$. Kwestia ta wymaga komentarza, a przede wszystkim odpowiedzi na pytanie, czy Nakielski mógł mieć wiedzę na temat tego instrumentu skoro wiadomo, że Miechów dwukrotnie uległ wielkim pożarom. Pierwszy z nich wybuchł w I379 r., a więc zaledwie trzy lata po instalacji instrumentu. Ze szczegółowego opisu w Roczniku miechowskim wynika, że pastwą płomieni padły budynki klasztorne oraz dzwonnica ${ }^{134}$. Jest możliwe, że sam kościół ocalał. Bożogrobcy wybudowali nowy kościół, którego prezbiterium było gotowe już w 1394 roku. Istotna wydaje się więc informacja, że powodem budowy nowej świątyni była groźba zawalenia się starego kościoła. Przesłanka ta wskazuje, że kościół nie uległ pożarowi, możliwe zatem, że ocalały także organy. Można na tej podstawie przypuszczać, że instrument z I376 r. został przeniesiony do nowego kościoła. Służył muzykom klasztornym przez całe XV stulecie. Nakielski wspomniał, opisując wielki pożar Miechowa w I506 r., że wraz z miastem i kościołem spłonęły organy ${ }^{135}$. Wzmianka ta świadczy o jego zainteresowaniu losami instrumentu. Byłby to zatem definitywny kres funkcjonowania starych, czternastowiecznych organów. Płynie stąd wniosek, że Nakielski nie mógł zatem znać go z autopsji i choć dysponował niezachowanymi dzisiaj źródłami z archiwum klasztornego, wątpliwe jest jednak bardzo, by był wśród nich opis instrumentu z I376 roku. Jak świadczą stosunkowo liczne wzmianki o organistach miechowskich z tego stulecia, świątynia bożogrobców odbudowana po pożarze z I506 r. została wyposażona w nowy instrument. Przyjmując, że Nakielski nie zmyślił informacji o liczbie głosów, należałoby stwierdzić, że znał on instrument szesnastowieczny. Dodam jeszcze, że dwudziestodwugłosowe organy miechowskie to na tamte czasy instrument duży, niewątpliwie wyposażony w klawiaturę nożną. Wybudowane w I534 r. nowe organy w kościele dominikańskim w Krakowie (dzieło dominikanina Klemensa z Mielca) miały dwanaście głosów w manuale i cztery głosy w pedale, a powietrze tłoczyły cztery miechy ${ }^{136}$.

I32 B. Brzezińska, op. cit.

I33 Samuel Nakielski, Miechovia sive Promptuarium Monasterii Miechoviensis, Cracoviae 1634 in officina Francisci Cesarij, s. 934, zach. Muzeum Ziemi Miechowskiej, sygn. 55 (372), online http://mbc. malopolska.pl/dlibra/docmetadata?id=I3734\&from=publication, dostęp Io IX 2018.

I34 Rocznik miechowski, op. cit. (zob. przyp. Io), s. I26.

I35 S. Nakielski, Miechovia sive, op. cit., s. 579.

I36 W. Kapeć, Organy i organiści, op. cit., s. Io8. 
Organy u franciszkanów w Nowym Sączu, wzmiankowane w I6I8 r., miały dziesięć głosów ${ }^{137}$. Wydaje się zatem, że za typowe klasztorne organy można uznać instrument kilkunastogłosowy z klawiaturą nożną. Dodamy jeszcze, że organy z I544 r. w kościele dominikanów krakowskich opisał Józef Sitarski w 1765 r. jako instrument o klawiaturze ręcznej „nieregularnej” oraz klawiaturze pedałowej „szczupłej i krótkiej” ${ }^{38}$.

Na zakończenie należy podkreślić, że nie ma żadnych wiarygodnych świadectw istnienia organów w klasztorach małopolskich w XIII wieku. Ich udokumentowane początki datują się na ostatnią ćwierć XIV stulecia. Z całą pewnością organy posiadał kościół bożogrobców w Miechowie, zaś w kościele Bożego Ciała w Kazimierzu konwent kanoników przejął w I405 r. organy istniejące od lat siedemdziesiątych XIV wieku. Za prawdopodobne można uznać istnienie w ostatniej ćwierci tego stulecia organów także u dominikanów krakowskich, benedyktynów tynieckich i augustianów kazimierskich. Nieco później poświadczone źródłowo są organy u franciszkanów, duchaków, augustianów i karmelitów, a także w niektórych klasztorach żeńskich. Dominują kościoły szeroko rozumianego zespołu osadniczego krakowskiego (Kraków, Kazimierz, Kleparz, przedmieścia i wsie podmiejskie). Dla drugiej połowy XIV i XV wieku. możemy mówić o zjawisku powszechnego wyposażenia kościołów klasztornych w organy. Najpóźniej budowa instrumentów postępowała w kościołach cysterskich i bernardyńskich. Sumując stan na koniec XVI w., uzyskujemy liczbę trzydziestu sześciu kościołów klasztornych posiadających te instrumenty muzyczne. Nie wiemy, jaki był wpływ zaawansowania technologicznego organmistrzostwa zachodniej Europy na polską sztukę. Nowoczesne rozwiązania techniczne docierały do Krakowa z ośrodków niemieckich, z którymi miasto utrzymywało, jak wiadomo, ożywione relacje. Organy posiadała katedra i wszystkie kościoły parafialne. Organmistrzostwo klasztorne i nieklasztorne nawzajem na siebie oddziaływały. Można także powiedzieć, że zaplecze technologiczne miały zarówno miasta, jak i klasztory. Klasztory wykorzystywały swoje własne kontakty zarówno z miastami, jak i klasztorami w Niemczech czy Czechach. Sięgały do zdobyczy ośrodków świeckich i kościelnych, co możemy wywnioskować z poświadczonych źródłowo wspólnych prac przy instrumencie w tym samym kościele zarówno organmistrzów-mieszczan, jak i zakonników. Przykład kazimierskiego kościoła Bożego Ciała wskazuje na swoistą symbiozę organmistrzostwa miejskiego i klasztornego. Wśród dziesiątków wzmianek o organistach grających w klasztorach małopolskich znajdujemy zarówno sylwetki zakonników, jak i duchownych niezakonnych, a także osoby świeckie. W Miechowie, ośrodku posiadającym dobrą dokumentację, obaj znani z XV w. organiści byli bożogrobcami. Mnich był pierwszym znanym nam organistą u benedyktynów tynieckich. U augustianów na Kazimierzu grał w I470 r. zakonnik, ale

I37 W. Z. Łyjak, „Organy w kościołach franciszkanów konwentualnych”, op. cit., s. 290. Adam Mączka, "Zapomniane klasztory franciszkańskie - Nowy Sącz”, W Nurcie Franciszkańskim II (2002), s. IIO. Autor wspomina o wzmiance z 1615 r. o nowych organach wartych 300 zł.

I38 W. Kapeć, Organy i organiśsci, op. cit., s. Io8. 
byli tu obecni także muzycy nieżyjący pod regułą. W kościołach cystersów organistami byli niemal wyłącznie mnisi. Z kolei pierwszy organista u duchaków, to mieszczanin krakowski. W kościele św. Marka pierwszym organistą był kanonik pełniący wysokie funkcje w zakonie. Widoczne w świetle źródeł zmienianie się organistów w tym samym kościele dowodzi otwartości konwentów na muzyków świeckich. Ogólnie rzecz biorąc, konkretne wzmianki o organistach-zakonnikach stanowią około 27\% ogółu wzmianek o organistach w kościołach klasztornych bądź pod patronatem klasztornym. Trudno stwierdzić, na ile odsetek ten oddaje rzeczywistość, gdyż z reguły nie mamy w źródłach odnotowanej profesji muzyka (wziąłem pod uwagę tylko te wzmianki, w których wyraźnie stwierdzono, że organista był zakonnikiem).

Wczesne wzmianki dotyczące bożogrobców, kanoników i dominikanów świadczą o tym, że na decyzję o wybudowaniu organów miały wpływ potrzeby oprawy muzycznej liturgii skierowanej do laikatu. Z drugiej zaś strony, przykłady benedyktynów, karmelitów i żeńskich klasztorów klauzurowych nie mają z taką motywacją nic wspólnego. Winniśmy zatem widzieć w średniowiecznych zakonach środowiska zainteresowane, po prostu, rozwojem muzyki organowej. Przypomnijmy, że najwcześniejsze i najcenniejsze polskie zbiory utworów organowych wiążą się z klasztorami małopolskimi. Ten fakt pozwala spojrzeć na klasztor jako na miejsce, w którym nie tylko tajniki konstrukcji, ale i umiejętności gry były przekazywane z pokolenia na pokolenie. Organy w kościele klasztornym stanowią ważny przejaw kultury muzycznej, są świadectwem troski o oprawę liturgii, dowodem na istnienie bodaj podstawowego księgozbioru z zapisem nutowym. Tabulatury klasztorne zwiastujące rozkwit muzyki organowej i wspaniałe dzieła barokowego organmistrzostwa - w klasztorach w Jędrzejowie, Wąchocku, Jasnej Górze czy Leżajsku - wyrosły na gruncie wielowiekowej tradycji.

\section{THE CONTRIBUTION OF MONASTERIES TO THE DEVELOPMENT OF ORGAN MUSIC CULTURE OF MAŁOPOLSKA IN THE MEDIEVAL AND EARLY MODERN PERIODS (FROM THE FOURTEENTH TO THE LATE SIXTEENTH CENTURIES)}

The source base for the conclusions presented in the article are the results of preliminary research in the sources generated by the monasteries (documents, financial records, inventories, obituaries, biograms of superiors, chronicles), manuscript court files of the bishop's court and the judicial vicar from the fifteenth and sixteenth centuries, and postinspection protocols and municipal records. In addition, the author took into account the existing literature on the subject. While analyzing the data found in the sources, the author puts forward the hypothesis that no references to pipe organs in monastic churches exist in sources from the thirteenth century - a source mentioning an organist in the Dominican church in Sandomierz, allegedly referring to I259, is open to questions and unreliable (in fact, it dates from as late as the eighteenth century). The first reference to a pipe organ in a monastic setting refers to the Church of the Holy Sepulchre in Miechów (1376). It was 
sponsored by the then provost Marcin Czcik. It should be emphasized that the monastic church in Miechów functioned at the same time as a parish church. The need to provide a music setting to religious services for the congregation was an important reason why the pipe organs were constructed in the Dominican and Franciscan churches in Cracow. The pipe organ in the Dominican church in Cracow were built in the first decade of the fifteenth century at the latest. Many references have survived to specific musicians in this church, while in the sixteenth century pipe organs in Dominican churches in other cities are mentioned. The construction of the pipe organ in the Church of St Francis dates back to a period before I445. In the sixteenth century, it was the best equipped church in the Cracow diocese when it came to musical instruments - two main pipe organs and a positive organ in each of the flanking chapels.

Important centres of music culture were located in the monasteries of the Canons Regular. Sources from the fifteenth and sixteenth centuries contain numerous references to names of specific organists employed at the Corpus Christi Church in the district of Kazimierz. In the sixteenth century, organ music was also performed in other churches of this order, most remarkably in the monastic church in Kraśnik (in this case, a complete list of sixteenth-century organists has survived). In the Church of the Holy Spirit in Cracow, the presence of an organist in confirmed in the sources from as early as 1443 . The Premonstratensian church in Brzesko-Hebdowo probably had a pipe organ as early as in the fifteenth century, the abbey in Nowy Sącz - in the sixteenth century, the St Mark Church of the Canons Regular of the Penance of the Blessed Martyrs in Cracow - in I54I. A separate subject are monastic churches with a purely conventual function. The presence of a pipe organ in the Benedictine church in Tyniec can be deduced from a reference to the organist - a Benedictine monk named Jan - from I405. It can be speculated that this church had a pipe organ as early as in the late fourteenth century. The origin of the pipe organ in the church in Łysa Góra are unclear, particularly attributing its foundation to King Ladislaus Jagiello. The pipe organ in the St Catherine Church of the Augustinian Order in Kazimierz, a remarkable centre of music culture, existed before 1436. In the second half of the fifteenth century, the church had two instruments. A reference to an organist in the Augustine church in Olkusz, a branch of the Kazimierz convent, comes from I494. There are no reliable sources for dating the pipe organs in Bernardine churches in the period before I600. The same holds for the Holy Virgin Mary Church at Jasna Góra, the conventual temple of the Pauline Order. In contrast to this state of knowledge, we know about a reference to an organist in the Pauline church at Skałka, providing evidence that a pipe organ existed there as early as in I475. Providing this temple with the instrument so early was undoubtedly influenced by the fact that it functioned as a parish church. As for the Carmelitan church, belonging to an order with a very strict rule and located in the suburban district of Garbary, the pipe organ existed there as early as in the first half of the fifteenth century, which was stimulated by the musical needs of the convent and the fact that the temple hosted an effigy of the Holy Virgin famous for various graces. In Cistercian churches, pipe organs were installed relatively late, which was also connected with the principles of the rule. In Mogiła, a pipe organ was constructed in the years 1522-46 and is the earliest example of a Cistercian pipe organ in Małopolska. The presence of a pipe organ 
in the Cistercian church in Jędrzejów is confirmed in 1573, and in Szczyrzyc in 1597. In all probability, in the same sixteenth century pipe organs were constructed in the churches in Koprzywnica and Wąchock, but there are no sources yet to substantiate this hypothesis. In female monasteries - Poor Clares in Cracow and Premonstratensians in Zwierzyniec and in Imbramowice - the activity of organists, and therefore the presence of instruments, is confirmed in the second half of the fifteenth century, despite the rules that excluded male presence in the premises. The activity of an organist in the Benedictine female convent in Staniątki is confirmed in I52I, while Poor Clares in Nowy Sącz had an organist in 1568 . The instrument in Nowy Sącz undoubtedly existed much earlier. In the monastic churches of female convents, organ music served only as accompaniment to choirs of nuns, because those churches were closed to laymen. If we additionally take into account sources from the late sixteenth century, it becomes possible to calculate that 36 monastic churches in Małopolska (in a territory overlapping with the Cracow diocese) possessed musical instruments. The collected references found in the sources prove that some monasteries (e.g. the Franciscan convent in Cracow) had their own workshops and supplied other churches. On the other hand, we notice that the convents would use the services of various organ-building centres as the builders employed for the purpose of constructing pipe organs were definitely not monks, or when organists employed elsewhere, e.g. in St Mary's Church, were hired as experts for the procedure of acceptance. References to musicians mentioned by name prove that they were recruited from three circles: the convent itself, non-monastic clergy and lay-organists. It is remarkable that e.g. in Cistercian temples only monks were accepted as organists. Information about the size of the instruments dates back to the sixteenth century and refers to the pipe organ in Miechów, which had 22 pitches, and to the instrument in the Dominican church in Cracow with I6 pitches. Monastic pipe organs were installed in different places in the temple: above the vaulting of the nave, on the side wall of the presbytery, on the wall above the altar, or above the western entry. In Małopolska, monasteries were places were the most precious works of organ music originated. The most famous of them are the Holy Ghost Tablature from Cracow and the Jan of Lublin Tablature. Both contain a number of compositions performed with a pedal keyboard. Also, they provide evidence that the monastic circles in Małopolska in the Middle Ages fostered a keen interest in the development of organ-building and organ music.

Translated by Pawet Gruchata

Słowa kluczowe/keywords: organy/organs, kościół/church, klasztor/monastery, zakon/convent, organista/organist, klawiatura/keyboard, tabulatura/tablature, parafia/parish

Prof. dr hab. Jerzy Rajman kieruje Katedrą Historii Średniowiecznej w Instytucie Historii Uniwersytetu Pedagogicznego w Krakowie. Zajmuje się historią Polski średniowiecznej, prowadzi badania nad dziejami zakonów, kultów świętych, historią Krakowa i osadnictwa Małopolski średniowiecznej (sylwetka naukowa i pełny wykaz publikacji na stronie www.up.krakow.pl). jerzy.rajman@poczta.fm 